IZA DP No. 6391

The Effects of Personality Traits on Adult Labor Market Outcomes: Evidence from Siblings

Jason M. Fletcher

February 2012 


\title{
The Effects of Personality Traits on Adult Labor Market Outcomes: Evidence from Siblings
}

\author{
Jason M. Fletcher \\ Yale University, \\ Columbia University and IZA \\ Discussion Paper No. 6391 \\ February 2012 \\ IZA \\ P.O. Box 7240 \\ 53072 Bonn \\ Germany \\ Phone: +49-228-3894-0 \\ Fax: +49-228-3894-180 \\ E-mail: iza@iza.org
}

\begin{abstract}
Any opinions expressed here are those of the author(s) and not those of IZA. Research published in this series may include views on policy, but the institute itself takes no institutional policy positions.

The Institute for the Study of Labor (IZA) in Bonn is a local and virtual international research center and a place of communication between science, politics and business. IZA is an independent nonprofit organization supported by Deutsche Post Foundation. The center is associated with the University of Bonn and offers a stimulating research environment through its international network, workshops and conferences, data service, project support, research visits and doctoral program. IZA engages in (i) original and internationally competitive research in all fields of labor economics, (ii) development of policy concepts, and (iii) dissemination of research results and concepts to the interested public.
\end{abstract}

IZA Discussion Papers often represent preliminary work and are circulated to encourage discussion. Citation of such a paper should account for its provisional character. A revised version may be available directly from the author. 


\section{ABSTRACT}

\section{The Effects of Personality Traits on Adult Labor Market Outcomes: Evidence from Siblings*}

While large literatures have shown that cognitive ability and schooling increases employment and wages, an emerging literature examines the importance of so-called "non-cognitive skills" in producing labor market outcomes. However, this smaller literature has not typically used causal methods in estimating the results. One source of heterogeneity that may play an important role in producing both personality and other non-cognitive skills and labor market outcomes is family background, including genetic endowments. This paper is the first to use sibling differences to estimate the effects of personality on employment and wages and is also able to control for many other sources of heterogeneity, including attractiveness, cognitive ability, schooling, occupation, and other factors. Overall, the findings suggest that personality measures are important determinants of labor market outcomes in adulthood and that the results vary considerably by demographic group. The findings also highlight the potential role of extraversion in leading to favorable labor market outcomes, which has not been documented in many other studies.

JEL Classification: J24, J31

Keywords: personality, wages, sibling fixed effects

Corresponding author:

Jason M. Fletcher

Yale University

Division of Health Policy and Administration

60 College Street, \#303

New Haven, CT 06520

USA

E-mail: jason.fletcher@yale.edu

\footnotetext{
* This research uses data from Add Health, a program project directed by Kathleen Mullan Harris and designed by J. Richard Udry, Peter S. Bearman, and Kathleen Mullan Harris at the University of North Carolina at Chapel Hill, and funded by grant P01-HD31921 from the Eunice Kennedy Shriver National Institute of Child Health and Human Development, with cooperative funding from 23 other federal agencies and foundations. Special acknowledgment is due Ronald R. Rindfuss and Barbara Entwisle for assistance in the original design. Information on how to obtain the Add Health data files is available on the Add Health website (http://www.cpc.unc.edu/addhealth). No direct support was received from grant P01-HD31921 for this analysis.
} 


\section{Introduction}

The associations between cognitive ability and labor market outcomes and other measures of economic success have been documented in multiple social science fields for several decades, with a long history in economics (Becker 1964, Griliches 1977). While psychologists and sociologists, among others, have also focused on the importance of so called "non cognitive skills", economists have only recently pursued this research (see Bowles, Gintis, and Osborne 2001 and Almlund et al. 2011 for reviews). This imbalance between research with a focus on cognitive skills relative to non-cognitive skills also stands in contrast to findings from several "gold standard" interventions, where non-cognitive skills have seemed to play a substantial role in benefits from programs. For example, the Perry Preschool Program, which was a randomized, expensive enrichment intervention for disadvantaged young children, has been shown to have major effects on life outcomes, measured through age 40, by fostering non-cognitive skills such as the ability to plan and execute plans and self-control, rather than measures of IQ (Heckman, Malofeeva, Pinto et al. 2010). Similarly, the long term follow up of Project STAR, a class size reduction program in Tennessee, indicates that, while test score increases were not maintained after the completion of the program, the long term impacts on outcomes could have been caused by the fostering of non-cognitive skills (Dee and West 2008, Chetty et al. 2010). Thus, increasing understanding of the links between specific measures of non-cognitive skills is an important area of inquiry.

There has been recent growth in the economic analysis of non-cognitive skills and economic success, and much of the research has focused on personality traits, as they seem to be linked to important socioeconomic measures. Overall, measures of conscientiousness have been found to be positively related to earnings, and measures of neuroticism are often negatively associated with labor market outcomes. However, the methods used to empirically link these personality measures are still advancing and the literature is not yet as mature as the research examining causal effects of cognitive skills. Indeed, little research to date has been able to control for family factors and genetic backgrounds that could affect both non-cognitive skill development and future life outcomes. This paper uses a national sample, with a large subsample of siblings and twins, to examine whether measures of personality are associated 
with labor market success as an adult. Findings suggest relatively large relationships between measures of extraversion that are comparable to the effects of skills or attractiveness. The links with conscientiousness are less robust, which is contrary to much of the earlier research in this area. The results also suggest important heterogeneity is some relationships by gender, childhood socioeconomic status, and race. Specifications that control from occupational sorting as well as educational attainment are often similar.

\section{Background Literature}

While the literature linking cognitive skills to economic success is a substantial area of economics research, as well as research in other social sciences, the effects of non-cognitive skills have only recently been examined by economists. Generally, an additional year of schooling has been shown to increase wages by 8-10\% per year (Card 1999). Likewise, IQ has been shown to increase labor market success (Mueller and Plug 2006). There is also evidence from the economics literature that non-cognitive skills, including measures of personality, are associated with labor market outcomes. Specifically, Cunha, Heckman, and Schennanch (2010) show that $12 \%$ of the variance in educational attainment is explained by personality measures (compared to $16 \%$ accounted for by cognitive ability measures). Almlund et al. (2011) survey the emerging literature and suggest that conscientiousness is the most predictive personality trait for educational attainment, achievement, and job performance, and most personality measures are related to sorting into occupations. Additionally, Goldberg et al (1998) and van Eijck and de Graaf (2004) show negative correlations between neuroticism, extraversion, and agreeableness and educational attainment.

In work examining personality and labor market outcomes, Almlund et al. (2011) summarize the literature as pointing to an important role for two personality measures, conscientiousness and neuroticism. For example, Nyhus and Pons (2005), Salgado (1997), and Hogan and Holland (2003) have each found important associations between conscientiousness and wages and job performance. Bowles et al. (2001) outline a conceptual framework linking wage premia with personality traits and suggest the source could include the degree of future orientation (in setting incentive schedules), personal efficacy, and reduced disutility of effort. 
What is personality, though? While there is a large literature in psychology and other disciplines that has sought to understand and categorize personality, Almlund et al. (2011) propose the interpretation that personality is a strategy function for responding to life situations, where personality traits and other influences are mapped into measured personality through the function. Indeed, a major theme from research in psychology is the stability of personality traits beginning in young adulthood (Mischell and Shoda 2008), and for some traits, like cognitive ability, that evolve early in life. For example, Roberts (2009) defines personality traits as "the relatively enduring patterns of thoughts, feelings, and behaviors that reflect the tendency to respond in certain ways under certain circumstances." Recently, economists have shown incredibly high stability in personality traits for working age individuals over a four year period (Cobb-Clark and Schurer 2011).

While there has been a long and overlapping history between measuring cognitive skills and personality (see Almlund et al. (2011) for details), in the 1970s psychologists coalesced around a widely shared list of key traits, the "Big Five", which are the highest level of personality traits (see McCrae and Costa 2008) ${ }^{1}$. These include: (1) Extraversion: An orientation of one's interests and energies toward the outer world of people and things rather than the inner world of subjective experience; characterized by positive affect and sociability (2) Neuroticism: a chronic level of emotional instability and proneness to psychological distress. Emotional stability is predictability and consistency in emotional reactions, with absence of rapid mood changes (3) Openness to Experience/Intellect: the tendency to be open to new aesthetic, cultural, or intellectual experiences (4) Conscientiousness: The tendency to be organized, responsible, and hardworking and (5) Agreeableness: The tendency to act in a cooperative, unselfish manner. This paper will link the Big Five personality traits with important labor market outcomes from a recent national sample of adults.

\footnotetext{
${ }^{1}$ Almlund et al. (2011) describes the origins of the Big Five model. They attribute the five-factor model to Allport and Odbert's (1936) lexical hypothesis, which posits that the most important individual differences are encoded in language. Allport and Odbert used English dictionaries and found over 17,000 personality-describing words, which were later reduced to approximately 4,500. The Big Five is then a composite, using factor analysis, of large sets of personality descriptions. For example, Extraversion is tied to adjectives such as Warmth (friendly) Gregariousness (sociable), Assertiveness (self-confident), Activity (energetic), Excitement seeking (adventurous), Positive emotions(enthusiastic) Gough and Heilbrun (1983).
} 


\section{Data and Methods}

The data in this study come from the confidential version of the National Longitudinal Study of Adolescent Health (Add Health). Add Health is a school-based, longitudinal study of the health-related behaviors of adolescents and their outcomes in young adulthood. Beginning with an in-school questionnaire administered to a nationally representative sample of students in grades 7 through 12 in 1994-95, the study follows up with a series of in-home interviews of students approximately one year and six years, and 13 years later ${ }^{2}$. Other sources of data include questionnaires for parents, siblings, fellow students, and school administrators. By design, the Add Health survey included a sample stratified by region, urbanicity, school type, ethnic mix, and size. Preexisting databases (e.g. census data) have been linked with the individuals in the sample and provide information about neighborhoods and communities. ${ }^{3}$

Of the 20,000 students surveyed during Wave 1 , nearly 15,000 have been followed longitudinally in the Wave 4 survey, when the respondents were 30 years old on average. At this time, labor market outcomes were assessed, as were the measures of the "Big Five" personality factors, including Extraversion, Neuroticism, Agreeableness, Conscientiousness, and Openness (see above) ${ }^{4}$. At times, researchers have been uncomfortable linking contemporaneous measures of personality with other socioeconomic outcomes, such as labor market outcomes, due to a concern with reverse causality, where poor job performance may increase measures of neuroticism, for example. However, as noted above, in addition to the large literature in psychology that suggest that by age 25-30, personality is stabile, new evidence based on working age adults from a national sample in Australia has shown that the Big Five measures of personality seem to be quite immune to fluctuations in life circumstances and should be thought of as stable traits for this age group (Cobb-Clark and Schurer 2011).

The respondents in Add Health have also been given a test of verbal IQ, the Peabody Picture Vocabulary Test, in Waves 1 and 3, which will serve as a measure of cognitive skills, as well as educational attainment at Wave 4. Ninety-three percent of the sample reported labor

\footnotetext{
${ }^{2}$ Brownstein et al. (2010) show that attrition between waves suggest little bias. Approximately $75 \%$ of the original sample was resurveyed at Wave 4.

${ }^{3}$ See Udry 2003 for full description of the Add Health data set. Also see for further information: http://www.cpc.unc.edu/projects/addhealth

${ }^{4}$ http://www.cpc.unc.edu/projects/addhealth/codebooks/wave4/sect26.zip shows the complete list of questions in the scales.
} 
earnings in the previous year and nearly $80 \%$ reported working for $10+$ hours the past week, which is the measure of employment status used in the paper. The earnings data from wave 4 come from the following question and are interval coded ${ }^{5}$ : "Now think about your personal earnings. How much income did you receive from personal earnings before taxes-that is, wages." Using this coding procedure, the average earnings for this sample of adults (average age nearly 30 ) is nearly $\$ 35,000$. As in standard social science surveys, a host of sociodemographic data has also been collected, including age, race, gender, and family background characteristics such as maternal education and income. The data also contains interviewer ratings of respondent attractiveness that have been shown to predict labor market outcomes in this sample (Fletcher 2009). Table 1 reports summary statistics. Table $1 \mathrm{~A}$ in the appendix shows that the characteristics of the sibling subsample closely mirrors the full sample. Table $2 \mathrm{~A}$ reports the summary statistics by gender and shows that males have higher attachment to the labor market and higher earnings $(\$ 40,000$ vs. $\$ 29,000)$. Although males and females attain the same scores on the verbal IQ test and attain similar education levels, they differ in their distributions of the personality subscales, where men are less extroverted, neurotic, agreeable and conscientious, but more open.

The empirical framework will follow a standard Mincer specification, where labor market outcomes are regressed on a set of demographic characteristics as well as cognitive and non-cognitive skills ${ }^{6}$ :

$$
y_{i}=\beta_{0}+\beta_{1}\left(\text { personality }_{i}\right)+\beta_{2}\left(\text { ability }_{i}\right)+\beta_{3} X_{i}+\varepsilon_{i}
$$

where $y_{i}$ is either employment status or an earnings outcome for individual $i$. In order to then control for common childhood neighborhood determinants of labor market outcomes and ability and potentially personality measures, high-school-of-origin fixed effects are included in an additional specification:

$$
y_{i s}=\beta_{0}+\beta_{1}\left(\text { personality }_{i}\right)+\beta_{2}\left(\text { ability }_{i}\right)+\beta_{3} X_{i}+\lambda_{s}+\varepsilon_{\text {is }}
$$

\footnotetext{
${ }^{5}$ The midpoint of each interval is used in the analysis. The intervals include: $\$ 0,<\$ 5,000, \$ 5,000-9,999,10,000$ 14,999, 15,000-19,999, 20,000-24,999, 25,000-29,999, 30,000-39,999, 40,000-49,999, 50,000-74,999, 75,00099,999, 100,000-149,999, 150,000 or more.

${ }^{6}$ See Almlund et al. (2011) for a Roy-model framework for examining personality effects on economic outcomes.
} 
Heckman, Stixrud and Urzua (2006) have shown that individuals sort into occupations and education based on personality measures. Thus, in order to examine additional potential omitted factors, I control for educational attainment, marital status, occupational fixed effects, and attractiveness:

$$
y_{i s}=\beta_{0}+\beta_{1}\left(\text { personality }_{i}\right)+\beta_{2}\left(\text { ability }_{i}\right)+\beta_{3} X_{i}+\beta_{4} Z_{i}+\lambda_{s}+\varepsilon_{\text {is }}
$$

Finally, in order to control for all common family attributes, I use sibling fixed effects in place of school fixed effects:

$$
y_{i f}=\beta_{0}+\beta_{1}\left(\text { personality }_{i}\right)+\beta_{2}\left(\text { ability }_{i}\right)+\beta_{3} W_{i}+\lambda_{f}+\varepsilon_{i f}
$$

where the $\mathrm{W}$ vector contains elements in $\mathrm{X}$ and $\mathrm{Z}$ that differ between siblings such as birth order, attractiveness, gender, age, and other variables listed below. As personality has been shown to be $40-60 \%$ heritable (Bouchard and Loehlin 2001) and labor market outcomes are strongly related to family background, these specifications will potentially reduced this unobserved heterogeneity and move closer to estimating causal effects of personality on labor market outcomes. One disadvantage of using sibling differences is the potential of measurement error in the personality characteristics reducing the signal to noise ratio of the measurement. However, Cobb-Clark and Schurer 2011 use data from a large population of middle age Australians to show that the median change in these measured Big 5 personality traits over four years is zero and fifty percent of individuals change no more than half a point (from a seven point scale). This suggests that measurement error may be of limited concern in the results. Another potential limitation with the analysis is unobserved parental responses and investments that may be related to personality and later labor market outcomes. Of course this issue is also true of all current research examining the effects of personality, but it should be noted when viewing the results ${ }^{7}$.

\footnotetext{
${ }^{7}$ An important consideration, though, is whether we think the parental or school investments are driven by personality or meant to change personality traits. The former case would arguably be a mechanism of the effects of personality on labor market outcomes rather than an omitted bias. There is very little evidence of the latter mechanism in the literature.
} 


\section{Results}

Table 2 begins by examining the associations between cognitive and non-cognitive skills and employment status around age $30 .^{8}$ The results suggest that a one standard deviation increase in extraversion increases employment by 2 percentage points. A one-standard deviation increase in neuroticism is also shown to reduce employment by 2.3-2.5 percentage points in columns 1-2. There are many potential omitted factors that do not allow these estimates to be given a causal interpretation. For example, Heckman, Stixrud and Urzua (2006) show that persons with different endowments of personality and intelligence sort into different occupations and levels of schooling. Thus, additional specifications are estimated to include controls for occupation and years of schooling, among others. Indeed, the effects are reduced considerably with occupation fixed effects, suggesting sorting, and are further reduced to zero with the inclusion of family fixed effects. In contrast, the results for extraversion only slightly decrease when controls for neighborhood, occupation, as well as family fixed effects; although the latter are no longer statistically significant, the point estimate does not decrease.

Measures of agreeableness, openness and conscientiousness have relatively small associations in the baseline results, but within families increase in importance. For example, a one standard deviation increase in conscientiousness increases employment by 3 percentage points and a similar increase in openness reduces employment by 2.8-3.6 percentage points, after controls for family fixed effects are used. These effects are of similar magnitude to the measures of cognitive skill and achievement in the data. A standard deviation increase in the high school measure of skill (PPVT score) is associated with an increase in employment of about 2 percentage points, as is a year increase in schooling. Unlike some previous research (Heckman, Humphries, and Urzua 2010), the association between personality measures and earnings is not explained by educational attainment, though this result is consistent with Cattan (2010) and Heckman, Stixrud, and Urzua (2006). The results also suggest that having below average attractiveness is associated with a 1.5-4 percentage point reduction in employment, while above average attractiveness increases the likelihood of employment by 3-6 percentage points.

\footnotetext{
${ }^{8}$ The results for an indicator for any earnings are similar and presented in the Appendix Table 3A.
} 
Table 3 stratifies the analyses from Table 2 by demographic subgroup to descriptively explore potential heterogeneity of effects. While many results are similar by group, the evidence suggests that the returns to extraversion are higher in women than men in the withinfamily analyses and there is some suggestion that extraversion increases employment more for individuals who grew up in low income household than those who group up in high income households. Also of note is that the return to the cognitive skills measure is much higher for females than males.

Table 4 examines log (earnings). Like the results for employment, there is consistent evidence that extraversion is associated with earnings. A one standard deviation increase in the extraversion subscale is associated with a 5-6\% earnings increase (approximately \$2,000 a year), which is robust over all the specifications. This result differs with findings from the Netherlands, where Nylus and Pons (2005) find negative effects of extraversion in their data. In addition, a one standard deviation increase in neuroticism reduces earnings by $5-9 \%$, which is consistent with much of the literature, including Nylus and Pons (2005). The results suggest that the effect of a one standard deviation increase in conscientiousness is to increase earnings by $3-6 \%$, which is consistent with the summary in Almlund et al. (2011), who suggests that this is the most replicated link between personality and wages in the literature(though Nylus and Pons find no effect). However, this effect is reduced to zero with family fixed effects. As a comparison, a one standard deviation increase in skill (PPVT score) is associated with earnings increase of up to $12 \%$ but is partially explained by family and occupational factors. To further place these magnitudes in context, the adjusted black-white earnings gap is $13-17 \%$ and the return to an extra year of schooling is between $9-10 \%$ in this sample. Similarly, the wage bonus from being above average attractiveness is $7-8 \%{ }^{9}$

Table 5 further stratifies the results for earnings based on gender, race, and household income during adolescence to descriptively examine potential heterogeneity of associations. Interestingly, the return to extraversion is found to be quite large for those individuals who grew up in low income households. The family fixed effects estimate suggests a $12 \%$ increase in

\footnotetext{
${ }^{9}$ Appendix Table 4A presents results that include earnings of zero, which typically increases the coefficients of interest. Likewise, Appendix Table 5A shows the results are robust to excluding the $2 \%$ of the sample who "guesses" their earnings.
} 
earnings for a one standard deviation increase in extraversion. The penalty for neuroticism appears for all groups, in contrast. While there is little consistency in the findings for agreeableness and openness, the effects for conscientious are relatively consistent without family fixed effects. Similarly, the return to skills (PPVT score) are also large and relatively similar across groups, although the family fixed effects specifications largely attenuate the results for males (brother pairs) and black siblings.

\section{Conclusions}

This study adds to the literature linking specific personality traits with labor market returns by using a recent national sample of young adults from the US. Methodologically, this study allowed controls for neighborhood effects, occupational sorting, as well as shared family background that could drive associations between personality and labor market success. A robust and relatively novel result is the large importance of extraversion in predicting labor market participation and wages. This result could reflect the differing composition of jobs in the US in recent years, specifically the growth of service jobs and the requirement of social interactions in the workplace. Interestingly, the result is not explained by occupational sorting and is large in magnitude compared with more traditional characteristics, such as cognitive skills and even attractiveness. The results also cast some doubt on the robustness of links between conscientiousness and earnings found in the prior literature-the effects are replicated in the baseline models but are then reduce substantially with the inclusion of sibling fixed effects. Measurement error is unlikely to be solely responsible for this reduction, based on evidence from Cobb-Clack and Schurer (2011) on the incredibly high stability and test-retest correspondence in these measures.

The results are also interesting in light of new interventions that seek to promote prosocial and non-cognitive skills in children, where these findings suggest the potential for important economic benefits for successful interventions. To the extent that personality measures also have a large genetic component (Bouchard and Loehlin (2001) review a large number of family studies that report heritability estimates between $40-60 \%$ ), the results also increase our understanding of the intergenerational transmission of inequality. 


\section{References}

Allport, Gordon W. and Odbert, Henry S. (1936). "Traitnames. A Psycho-Lexical Study." Psychological Monographs.47: 171.

Almlund, Mathilde, Angela Lee Duckworth, James Heckman, and Tim Kautz. (2011).

"Personality Psychology and Economics." IZA Discussion Paper 5500

Becker, Gary S. (1964). Human Capital: A Theoretical and Empirical Analysis, with Special Reference to Education. New York, National Bureau of Economic Research, distributed by Columbia University Press.

Borghans, Lex, Duckworth, Angela L., Heckman, James J. and ter Weel, Bas (2008). "The Economics and Psychology of Personality Traits." Journal of Human Resources 43(4): 972-1059.

Bouchard, Thomas and John C. Loehlin. (2001). "Genes, Evolution, and Personality." Behavioral Genetics, 31(3): 243-273

Bowles, Samuel, Gintis, Herbert and Osborne, Melissa (2001). "The Determinants of Earnings: A Behavioral Approach." Journal of Economic Literature 39(4): 1137-1176.

Brownstein Naomi, William D. Kalsbeek, Joyce Tabor, Pamela Entzel, Eric Daza, and Kathleen Mullan Harris (2010). "Non-Response in Wave IV of the National Longitudinal Study of Adolescent Health." Add Health Report:

http://www.cpc.unc.edu/projects/addhealth/data/guides/W4 nonresponse.pdf

Cattan, Sarah (2010). "Heterogeneity and Selection in the Labor Market." PhD Thesis, Economics Department, University of Chicago.

Chetty, Raj, Friedman, John N., Hilger, Nathaniel, Saez, Emmanuel, Diane, Schanzenbach Whitmore and Yagan, Danny (2010). "How Does Your Kindergarten Classroom Affect Your Earnings? Evidence from Project Star." NBER Working Paper No. 16381.

Cobb-Clark, Deborah and Bonnie Schurer (2011). "The Stability of Big-Five Personality Traits." IZA Discussion Paper 5943

Cunha, Flavio, Heckman, James J. and Schennach, Susanne M. (2010). "Estimating the Technology of Cognitive and Noncognitive Skill Formation." Econometrica 78(3): 883931. 
Dee, Thomas and West, Martin (2008). "The Non-Cognitive Returns to Class Size." NBER Working Paper No. 13994.

Gough, Harrison G. and Heilbrun, Alfred B. (1983). The Adjective Check List Manual. Palo Alto, CA, Consulting Psychologists Press.

Goldberg, Lewis R., Sweeney, Dennis, Merenda, Peter F. and Hughes, John Edward, Jr. (1998).

"Demographic Variables and Personality: The Effects of Gender, Age, Education, and Ethnic/Racial Status on Self-Descriptions of Personality Attributes." Personality and Individual Differences 24(3): 393-403.

Goldsmith, A., Veum, J., \& Darity, W. (1997). The impact of psychological and human capital on wages. Economic Inquiry, 35, 815-829.

Goldsmith, A., Veum, J., \& Darity, W. (2000). Working hard for the money? Efficiency wages and worker effort. Journal of Economic Psychology, 21, 351-385.

Griliches, Zvi (1977). "Estimating the Returns to Schooling: Some Econometric Problems." Econometrica 45(1): 1-22.

Heckman, James J., Humphries, John Eric, Urzua, Sergio and Veramendi, Gregory (2010). "The Effects of Schooling on Labor Market and Health Outcomes." Unpublished Manuscript. University of Chicago, Department of Economics.

Heckman, James J., Malofeeva, Lena, Pinto, Rodrigo and Savelyev, Peter A. (2010). "Understanding the Mechanisms through Which an Influential Early Childhood Program Boosted Adult Outcomes." Unpublished manuscript. Department of Economics, University of Chicago.

Heckman, James J., Stixrud, Jora and Urzua, Sergio (2006). "The Effects of Cognitive and Noncognitive Abilities on Labor Market Outcomes and Social Behavior." Journal of Labor Economics 24(3): 411-482.

Heineck, Guido and Silke Anger. (2010). "The Returns to Cognitive Abilities and Personality Traits in Germany." Labour Economics 17: 535-546

Hogan, Joyce and Holland, Brent (2003). "Using Theory to Evaluate Personality and Job- 
Performance Relations: A Socioanalytic Perspective." Journal of Applied Psychology 88(1): 100-112.

McCrae, Robert R. and Costa, Paul T. Jr. (2008). "The Five-Factor Theory of Personality." in Handbook of Personality: Theory and Research. O. P. John, R. W. Robins and L. A. Pervin, eds. New York, NY, The Guilford Press: 159-181.

Mischel, Walter and Shoda, Yuichi (2008). "Toward a Unifying Theory of Personality: Integrating Dispositions and Processing Dynamics within the Cognitive-Affective Processing System." in Handbook of Personality Psychology. O. P. John, R. W. Robins and L. A. Pervin, eds. New York, Guilford Press: 209-241.

Mueller, G., Plug, E., (2006). Estimating the effects of personality on male and female earnings. Industrial and Labor Relations Review 60 (1), 3-22.

Nyhus, Ellen K. and Pons, Empar (2005). "The Effects of Personality on Earnings." Journal of Economic Psychology 26(3): 363-384.

Roberts, Brent W. (2009). "Back to the Future: Personality and Assessment and Personality Development." Journal of Research in Personality 43(2): 137-145.

Salgado, Jésus F. (1997). "The Five Factor Model of Personality and Job Performance in the European Community." Journal of Applied Psychology 82(1): 30-43.

van Eijck, Koen and de Graaf, Paul M. (2004). "The Big Five at School: The Impact of Personality on Educational Attainment." Netherlands' Journal of Social Sciences 40(1):

24-40. 
Tables

Table 1

Descriptive Statistics: Add Health

\begin{tabular}{|c|c|c|c|c|c|c|}
\hline Variable & Wave & Obs & Mean & Std Dev & Min & Max \\
\hline Any Income & 4 & 14527 & 0.93 & 0.25 & 0 & 1 \\
\hline Work (10+ Hours) & 4 & 12304 & 0.77 & 0.42 & 0 & 1 \\
\hline Earnings & 4 & 14527 & 34232.25 & 37594.21 & 0 & 920000 \\
\hline Log(Earnings) & 4 & 13523 & 10.15 & 1.04 & 1 & 14 \\
\hline Log(Earnings) with Zeros & 4 & 14527 & 9.29 & 3.31 & -2 & 14 \\
\hline Earnings Guess & 4 & 14527 & 0.03 & 0.16 & 0 & 1 \\
\hline Extraversion Scale & 4 & 14527 & 13.23 & 3.06 & 4 & 20 \\
\hline Neuroticism Scale & 4 & 14527 & 10.43 & 2.74 & 4 & 20 \\
\hline Agreeableness Scale & 4 & 14527 & 15.26 & 2.41 & 4 & 20 \\
\hline Conscientiousness Scale & 4 & 14527 & 14.65 & 2.69 & 4 & 20 \\
\hline Openness Scale & 4 & 14527 & 14.50 & 2.45 & 4 & 20 \\
\hline Extraversion Scale (std) & 4 & 14527 & 0.00 & 1.00 & -3 & 2 \\
\hline Neuroticism Scale (std) & 4 & 14527 & -0.01 & 1.00 & -2 & 3 \\
\hline Agreeableness Scale (std) & 4 & 14527 & 0.01 & 1.00 & -5 & 2 \\
\hline Conscientiousness Scale (std) & 4 & 14527 & 0.00 & 1.00 & -4 & 2 \\
\hline Openness Scale (std) & 4 & 14527 & 0.00 & 1.00 & -4 & 2 \\
\hline Age & 4 & 14527 & 28.97 & 1.75 & 24 & 35 \\
\hline Female & All & 14527 & 0.54 & 0.50 & 0 & 1 \\
\hline PPVT Score & 1 & 14527 & 100.80 & 14.44 & 13 & 146 \\
\hline Maternal Education & 1 & 14527 & 13.22 & 2.24 & 0 & 17 \\
\hline Family Income & 1 & 14527 & 46.12 & 42.17 & 0 & 990 \\
\hline Married Parents & 1 & 14527 & 0.71 & 0.42 & 0 & 1 \\
\hline Hispanic & All & 14527 & 0.16 & 0.37 & 0 & 1 \\
\hline Black & All & 14527 & 0.22 & 0.41 & 0 & 1 \\
\hline Rural & 1 & 14527 & 0.26 & 0.43 & 0 & 1 \\
\hline Missing Family Information & 1 & 14527 & 0.31 & 0.46 & 0 & 1 \\
\hline Grade $=8$ & 1 & 14205 & 0.14 & 0.35 & 0 & 1 \\
\hline Grade $=9$ & 1 & 14205 & 0.18 & 0.39 & 0 & 1 \\
\hline Grade $=10$ & 1 & 14205 & 0.19 & 0.40 & 0 & 1 \\
\hline Grade $=11$ & 1 & 14205 & 0.19 & 0.39 & 0 & 1 \\
\hline Grade $=12$ & 1 & 14205 & 0.16 & 0.36 & 0 & 1 \\
\hline PPVT Score & 3 & 14527 & 101.08 & 14.14 & 9 & 123 \\
\hline Missing PPVT & 3 & 14527 & 0.19 & 0.39 & 0 & 1 \\
\hline Below Average Attractiveness & 4 & 14504 & 0.07 & 0.26 & 0 & 1 \\
\hline Above Average Attractiveness & 4 & 14504 & 0.46 & 0.50 & 0 & 1 \\
\hline Education & 4 & 14525 & 14.29 & 2.06 & 8 & 21 \\
\hline Ever Married & 4 & 14520 & 0.50 & 0.50 & 0 & 1 \\
\hline
\end{tabular}


Table 2

Associations Between Employment Status and Cognitive and Non-Cognitive Skills

Baseline, School, Occupation, and Family Fixed Effects

\begin{tabular}{|c|c|c|c|c|c|}
\hline Outcome & Employment & Employment & Employment & Employment & Employment \\
\hline Fixed Effects? & None & School & Occupation & Family & Family \\
\hline Xs & Basic & Basic & Extra & Basic & Extra \\
\hline \multirow[t]{2}{*}{ Extraversion (std) } & $0.021 * * *$ & $0.019 * * *$ & $0.017 * *$ & 0.023 & 0.017 \\
\hline & $(0.006)$ & $(0.006)$ & $(0.006)$ & $(0.016)$ & $(0.016)$ \\
\hline \multirow[t]{2}{*}{ Neuroticism (std) } & $-0.023 * * *$ & $-0.025 * * *$ & $-0.015 * * *$ & 0.001 & 0.003 \\
\hline & $(0.006)$ & $(0.006)$ & $(0.005)$ & $(0.014)$ & $(0.014)$ \\
\hline \multirow[t]{2}{*}{ Agreeableness (std) } & -0.005 & -0.005 & $-0.011 * * *$ & 0.021 & 0.024 \\
\hline & $(0.006)$ & $(0.006)$ & $(0.003)$ & $(0.017)$ & $(0.017)$ \\
\hline \multirow[t]{2}{*}{ Conscientiousness (std) } & 0.009 & 0.007 & -0.001 & $0.035 * *$ & $0.028^{*}$ \\
\hline & $(0.006)$ & $(0.006)$ & $(0.003)$ & $(0.015)$ & $(0.014)$ \\
\hline \multirow[t]{2}{*}{ Openness (std) } & -0.002 & -0.003 & -0.004 & $-0.028^{*}$ & $-0.036 * *$ \\
\hline & $(0.005)$ & $(0.005)$ & $(0.004)$ & $(0.016)$ & $(0.015)$ \\
\hline \multirow[t]{2}{*}{ Age } & $-0.033 * * *$ & $-0.036 * * *$ & $-0.010 * *$ & 0.001 & 0.006 \\
\hline & $(0.009)$ & $(0.009)$ & $(0.005)$ & $(0.009)$ & $(0.009)$ \\
\hline \multirow[t]{2}{*}{ Female } & $-0.080 * * *$ & $-0.081 * * *$ & $-0.095 * * *$ & $-0.127 * * *$ & $-0.141 * * *$ \\
\hline & $(0.013)$ & $(0.013)$ & $(0.016)$ & $(0.034)$ & $(0.033)$ \\
\hline \multirow[t]{2}{*}{ PPVT Score (W1) } & $0.027 * * *$ & $0.018 * *$ & 0.004 & 0.022 & 0.021 \\
\hline & $(0.007)$ & $(0.007)$ & $(0.006)$ & $(0.022)$ & $(0.023)$ \\
\hline \multirow[t]{2}{*}{ Parents Married } & $0.026^{*}$ & 0.015 & $0.025 * * *$ & & \\
\hline & $(0.014)$ & $(0.014)$ & $(0.009)$ & & \\
\hline \multirow[t]{2}{*}{ Hispanic } & $0.046 * *$ & 0.030 & $0.030 * * *$ & & \\
\hline & $(0.019)$ & $(0.022)$ & $(0.009)$ & & \\
\hline \multirow[t]{2}{*}{ Black } & -0.009 & -0.019 & -0.008 & & \\
\hline & $(0.017)$ & $(0.023)$ & (0.019) & & \\
\hline \multirow[t]{2}{*}{ PPVT Score (W3) } & & & -0.002 & & $-0.032 *$ \\
\hline & & & $(0.005)$ & & $(0.019)$ \\
\hline \multirow[t]{2}{*}{ Education } & & & $0.016 * * *$ & & $0.029 * * *$ \\
\hline & & & $(0.004)$ & & $(0.009)$ \\
\hline \multirow[t]{2}{*}{ Ever Married } & & & $-0.036 * *$ & & $-0.088 * * *$ \\
\hline & & & $(0.015)$ & & $(0.029)$ \\
\hline \multirow[t]{2}{*}{ Below Average Attractiveness } & & & $-0.039 * *$ & & -0.015 \\
\hline & & & $(0.016)$ & & $(0.051)$ \\
\hline \multirow[t]{2}{*}{ Above Average Attractiveness } & & & $0.031 * * *$ & & $0.059 * *$ \\
\hline & & & $(0.008)$ & & $(0.029)$ \\
\hline Observations & 11,343 & 11,343 & 11,748 & 1,957 & 1,954 \\
\hline R-squared & 0.037 & 0.064 & 0.033 & 0.033 & 0.060 \\
\hline Number of Families & & & & 1,077 & 1,076 \\
\hline
\end{tabular}

$1 \%{ }^{* * *}, 5 \% * *, 10 \% *$, Robust Standard Errors clustered at the school or family level. Omitted Controls: Grade Level at Wave 1 Dummies, Missing PPVT W3 Score, Missing Family Information, Rural Status, Constant, Family Income, Maternal Education 
Table 3

Stratified Associations Between Employment Status and Cognitive and Non-Cognitive Skills

\begin{tabular}{|lcccccccc}
\hline Outcome & Employment & Employment & Employment & Employment & Employment & Employment & Employment \\
Sample & Male & Female & White & Black & Hispanic & Rich & Poor \\
Fixed Effects & None & None & None & None & None & None & None \\
Extraversion (std) & $0.022^{* * *}$ & $0.020^{* *}$ & $0.022^{* * *}$ & 0.007 & $0.038^{* *}$ & $0.018^{* *}$ & $0.025^{* * *}$ \\
& $(0.008)$ & $(0.009)$ & $(0.007)$ & $(0.013)$ & $(0.018)$ & $(0.009)$ & $(0.008)$ \\
Neuroticism (std) & $-0.025^{* * *}$ & $-0.020^{* *}$ & $-0.026^{* * *}$ & $-0.035^{* *}$ & 0.002 & $-0.017^{* *}$ & $-0.028^{* * *}$ \\
& $(0.008)$ & $(0.009)$ & $(0.007)$ & $(0.014)$ & $(0.015)$ & $(0.008)$ & $(0.010)$ \\
Agreeableness (std) & 0.003 & $-0.013^{*}$ & -0.004 & 0.014 & $-0.033^{*}$ & 0.005 & $-0.019^{*}$ \\
& $(0.008)$ & $(0.008)$ & $(0.007)$ & $(0.015)$ & $(0.018)$ & $(0.010)$ & $(0.012)$ \\
Conscientiousness (std) & -0.002 & $0.022^{* * *}$ & $0.017^{* *}$ & -0.020 & 0.014 & 0.011 & $0.018^{*}$ \\
& $(0.009)$ & $(0.008)$ & $(0.007)$ & $(0.012)$ & $(0.016)$ & $(0.008)$ & $(0.010)$ \\
Openness (std) & -0.011 & 0.009 & -0.001 & 0.012 & -0.027 & -0.006 & -0.004 \\
& $(0.008)$ & $(0.008)$ & $(0.007)$ & $(0.015)$ & $(0.019)$ & $(0.009)$ & $(0.010)$ \\
PPVT Score (W1) & 0.015 & $0.039 * * *$ & 0.010 & $0.049 * * *$ & $0.064^{* * *}$ & 0.007 & $0.032^{* *}$ \\
& -0.011 & $(0.009)$ & $(0.010)$ & $(0.016)$ & $(0.012)$ & $(0.011)$ & $(0.013)$ \\
& & & & & & & 4,319 \\
Observations & 5,294 & 6,049 & 6,374 & 2,477 & 1,747 & 4,342 & 4,319 \\
R-squared & 0.038 & 0.037 & 0.040 & 0.076 & 0.106 & 0.032 & 0.051 \\
Number of Families & & & & & & & \\
\hline
\end{tabular}

\begin{tabular}{|lcccccccc}
\hline Outcome & Employment & Employment & Employment & Employment & Employment & \multicolumn{2}{c|}{ Employment } & Employment \\
Sample & Male & Female & White & Black & Hispanic & Rich & Poor \\
Fixed Effects & Family & Family & Family & Family & Family & Family & Family \\
Extraversion (std) & 0.018 & $0.059 * *$ & 0.020 & 0.036 & 0.029 & 0.021 & 0.036 \\
& $(0.025)$ & $(0.030)$ & $(0.021)$ & $(0.028)$ & $(0.048)$ & $(0.025)$ & $(0.026)$ \\
Neuroticism (std) & -0.008 & 0.039 & 0.007 & -0.023 & 0.019 & 0.011 & -0.009 \\
& $(0.021)$ & $(0.028)$ & $(0.018)$ & $(0.031)$ & $(0.041)$ & $(0.019)$ & $(0.025)$ \\
Agreeableness (std) & $0.055^{* *}$ & -0.008 & 0.020 & 0.021 & 0.025 & -0.002 & 0.030 \\
& $(0.023)$ & $(0.035)$ & $(0.024)$ & $(0.032)$ & $(0.049)$ & $(0.027)$ & $(0.026)$ \\
Conscientiousness (std) & 0.025 & 0.029 & $0.040 * *$ & 0.051 & -0.014 & $0.056 * *$ & 0.024 \\
& $(0.027)$ & $(0.025)$ & $(0.018)$ & $(0.033)$ & $(0.041)$ & $(0.023)$ & $(0.022)$ \\
Openness (std) & -0.000 & $-0.069 * * *$ & -0.024 & -0.020 & $-0.107 * *$ & -0.018 & $-0.070 * *$ \\
& $(0.022)$ & $(0.026)$ & $(0.021)$ & $(0.035)$ & $(0.046)$ & $(0.026)$ & $(0.027)$ \\
PPVT Score (W1) & -0.017 & 0.070 & -0.002 & -0.014 & 0.087 & 0.007 & 0.044 \\
& $(0.036)$ & $(0.051)$ & $(0.035)$ & $(0.034)$ & $(0.067)$ & $(0.031)$ & $(0.040)$ \\
& & & & & & 257 & 721 & 804 \\
Observations & 586 & 665 & 1,150 & 421 & 257 & 0.045 \\
R-squared & 0.047 & 0.044 & 0.052 & 0.055 & 0.140 & 0.075 & 0.046 \\
Number of Families & 332 & 373 & 652 & 229 & 152 & 419 & 452 \\
\hline
\end{tabular}

$1 \%^{* * *}, 5 \%^{* *}, 10 \% *$, Robust Standard Errors clustered at the school or family level. Same controls as previous table. Rich: above median household income at wave 1. Poor: below median household income at wave 1. 
Table 4

Associations Between Log(Earnings) and Cognitive and Non-Cognitive Skills

Baseline, School, Occupation, and Family Fixed Effects

\begin{tabular}{|c|c|c|c|c|c|}
\hline Outcome & $\begin{array}{c}\text { Log } \\
\text { (Earnings) }\end{array}$ & $\begin{array}{c}\text { Log } \\
\text { (Earnings) }\end{array}$ & $\begin{array}{c}\text { Log } \\
\text { (Earnings) }\end{array}$ & $\begin{array}{c}\text { Log } \\
\text { (Earnings) }\end{array}$ & $\begin{array}{c}\text { Log } \\
\text { (Earnings) }\end{array}$ \\
\hline Fixed Effects? & None & School & Occupation & Family & Family \\
\hline Xs & Basic & Basic & Extra & Basic & Extra \\
\hline Extraversion (std) & $\begin{array}{c}0.062^{* * *} \\
(0.012)\end{array}$ & $\begin{array}{c}0.054^{* * *} \\
(0.012)\end{array}$ & $\begin{array}{c}0.066^{* * *} \\
(0.009)\end{array}$ & $\begin{array}{l}0.058^{*} \\
(0.031)\end{array}$ & $\begin{array}{l}0.053^{*} \\
(0.030)\end{array}$ \\
\hline Neuroticism (std) & $\begin{array}{c}-0.085^{* * *} \\
(0.016)\end{array}$ & $\begin{array}{c}-0.083^{* * *} \\
(0.015)\end{array}$ & $\begin{array}{c}-0.045^{* * *} \\
(0.006)\end{array}$ & $\begin{array}{c}-0.060 * \\
(0.031)\end{array}$ & $\begin{array}{l}-0.050 \\
(0.030)\end{array}$ \\
\hline Agreeableness (std) & $\begin{array}{c}0.000 \\
(0.013)\end{array}$ & $\begin{array}{c}0.002 \\
(0.014)\end{array}$ & $\begin{array}{c}-0.031^{* * *} \\
(0.011)\end{array}$ & $\begin{array}{l}-0.027 \\
(0.035)\end{array}$ & $\begin{array}{l}-0.046 \\
(0.034)\end{array}$ \\
\hline Conscientiousness (std) & $\begin{array}{c}0.060 * * * \\
(0.011)\end{array}$ & $\begin{array}{c}0.057^{* * *} \\
(0.012)\end{array}$ & $\begin{array}{c}0.030 * * * \\
(0.009)\end{array}$ & $\begin{array}{c}0.002 \\
(0.029)\end{array}$ & $\begin{array}{l}-0.010 \\
(0.028)\end{array}$ \\
\hline Openness (std) & $\begin{array}{c}-0.011 \\
(0.020)\end{array}$ & $\begin{array}{c}-0.035^{* *} \\
(0.014)\end{array}$ & $\begin{array}{c}-0.042^{* * *} \\
(0.009)\end{array}$ & $\begin{array}{c}0.031 \\
(0.033)\end{array}$ & $\begin{array}{c}0.025 \\
(0.033)\end{array}$ \\
\hline Age & $\begin{array}{c}-0.102 * * * \\
(0.023)\end{array}$ & $\begin{array}{c}-0.097 * * * \\
(0.021)\end{array}$ & $\begin{array}{c}-0.053^{* * *} \\
(0.016)\end{array}$ & $\begin{array}{c}0.064^{* * *} \\
(0.018)\end{array}$ & $\begin{array}{c}0.048 * * * \\
(0.018)\end{array}$ \\
\hline Female & $\begin{array}{c}-0.328 * * * \\
(0.037)\end{array}$ & $\begin{array}{c}-0.347^{* * *} \\
(0.033)\end{array}$ & $\begin{array}{c}-0.286 * * * \\
(0.046)\end{array}$ & $\begin{array}{c}-0.314^{* * *} \\
(0.066)\end{array}$ & $\begin{array}{c}-0.361^{* * *} \\
(0.066)\end{array}$ \\
\hline PPVT Score (W1) & $\begin{array}{c}0.119 * * * \\
(0.024)\end{array}$ & $\begin{array}{c}0.094^{* * *} \\
(0.016)\end{array}$ & $\begin{array}{l}0.029 * \\
(0.016)\end{array}$ & $\begin{array}{c}0.064 \\
(0.046)\end{array}$ & $\begin{array}{c}0.021 \\
(0.046)\end{array}$ \\
\hline Parents Married & $\begin{array}{c}0.098^{* *} \\
(0.046)\end{array}$ & $\begin{array}{c}0.058 \\
(0.040)\end{array}$ & $\begin{array}{l}0.051^{*} \\
(0.025)\end{array}$ & & \\
\hline Hispanic & $\begin{array}{c}0.042 \\
(0.053)\end{array}$ & $\begin{array}{c}-0.022 \\
(0.056)\end{array}$ & $\begin{array}{c}0.007 \\
(0.028)\end{array}$ & & \\
\hline Black & $\begin{array}{c}-0.168 * * * \\
(0.059)\end{array}$ & $\begin{array}{c}-0.193 * * * \\
(0.054)\end{array}$ & $\begin{array}{c}-0.137^{* * *} \\
(0.029)\end{array}$ & & \\
\hline PPVT Score (W3) & & & $\begin{array}{c}0.007 \\
(0.013)\end{array}$ & & $\begin{array}{c}0.019 \\
(0.034)\end{array}$ \\
\hline Education & & & $\begin{array}{c}0.102^{* * *} \\
(0.013)\end{array}$ & & $\begin{array}{c}0.088 * * * \\
(0.017)\end{array}$ \\
\hline Ever Married & & & $\begin{array}{c}0.091^{* * *} \\
(0.028)\end{array}$ & & $\begin{array}{c}0.128^{* *} \\
(0.053)\end{array}$ \\
\hline Below Average Attractiveness & & & $\begin{array}{c}-0.082^{* *} \\
(0.033)\end{array}$ & & $\begin{array}{c}0.044 \\
(0.109)\end{array}$ \\
\hline Above Average Attractiveness & & & $\begin{array}{c}0.083^{* * *} \\
(0.023)\end{array}$ & & $\begin{array}{c}0.073 \\
(0.055)\end{array}$ \\
\hline Observations & 12,529 & 12,529 & 12,998 & 2,175 & 2,171 \\
\hline R-squared & 0.129 & 0.190 & 0.107 & 0.061 & 0.089 \\
\hline Number of Families & & & & 1,107 & 1,107 \\
\hline
\end{tabular}

$1 \% * *, 5 \% * *, 10 \% *$, Robust Standard Errors clustered at the school or family level. Omitted Controls: Grade Level at Wave 1 Dummies, Missing PPVT W3 Score, Missing Family Information, Rural Status, Constant, Family Income, Maternal Education 
Table 5

Stratified Associations Between Log Earnings and Cognitive and Non-Cognitive Skills

\begin{tabular}{|c|c|c|c|c|c|c|c|}
\hline Outcome & Log Earnings & Log Earnings & Log Earnings & Log Earnings & Log Earnings & Log Earnings & Log Earnings \\
\hline Sample & Male & Female & White & Black & Hispanic & Rich & Poor \\
\hline Fixed Effects & None & None & None & None & None & None & None \\
\hline \multirow[t]{2}{*}{ Extraversion (std) } & $0.098 * * *$ & 0.021 & $0.052 * * *$ & $0.072 * * *$ & $0.141^{* * *}$ & $0.072 * * *$ & $0.054 * *$ \\
\hline & $(0.017)$ & $(0.016)$ & $(0.016)$ & $(0.024)$ & $(0.038)$ & $(0.016)$ & $(0.022)$ \\
\hline \multirow[t]{2}{*}{ Neuroticism (std) } & $-0.079 * * *$ & $-0.089 * * *$ & $-0.086 * * *$ & $-0.105^{* * *}$ & -0.058 & $-0.076 * * *$ & $-0.101 * * *$ \\
\hline & $(0.019)$ & $(0.019)$ & $(0.019)$ & $(0.033)$ & $(0.053)$ & $(0.018)$ & $(0.024)$ \\
\hline \multirow{2}{*}{ Agreeableness (std) } & -0.006 & 0.019 & 0.009 & 0.030 & -0.046 & 0.005 & -0.006 \\
\hline & $(0.018)$ & $(0.021)$ & $(0.018)$ & $(0.038)$ & $(0.045)$ & $(0.020)$ & $(0.020)$ \\
\hline \multirow[t]{2}{*}{ Conscientiousness (std) } & $0.050 * * *$ & $0.075^{* * *}$ & $0.079 * * *$ & -0.014 & 0.045 & $0.039 * *$ & $0.062 * * *$ \\
\hline & $(0.016)$ & $(0.016)$ & $(0.014)$ & (0.029) & $(0.032)$ & $(0.016)$ & $(0.022)$ \\
\hline \multirow[t]{2}{*}{ Openness (std) } & $-0.050 *$ & 0.031 & -0.023 & -0.045 & 0.105 & $-0.038^{*}$ & 0.026 \\
\hline & $(0.027)$ & $(0.022)$ & $(0.016)$ & $(0.038)$ & $(0.091)$ & $(0.020)$ & $(0.041)$ \\
\hline \multirow[t]{2}{*}{ PPVT Score (W1) } & $0.146 * * *$ & $0.092 * * *$ & $0.109 * * *$ & $0.168 * * *$ & $0.148 * *$ & $0.091 * * *$ & $0.128 * * *$ \\
\hline & $(0.032)$ & $(0.026)$ & $(0.022)$ & $(0.042)$ & $(0.066)$ & $(0.024)$ & $(0.042)$ \\
\hline Observations & 6,050 & 6,479 & 6,963 & 2,680 & 2,014 & 4,960 & 4,615 \\
\hline R-squared & 0.116 & 0.111 & 0.136 & 0.138 & 0.098 & 0.110 & 0.095 \\
\hline
\end{tabular}

\begin{tabular}{|c|c|c|c|c|c|c|c|}
\hline Outcome & Log Earnings & Log Earnings & Log Earnings & Log Earnings & Log Earnings & Log Earnings & Log Earnings \\
\hline Sample & Male & Female & White & Black & Hispanic & Rich & Poor \\
\hline Fixed Effects & Family & Family & Family & Family & Family & Family & Family \\
\hline \multirow[t]{2}{*}{ Extraversion (std) } & 0.033 & 0.047 & 0.033 & 0.105 & 0.007 & 0.056 & $0.121 * *$ \\
\hline & $(0.056)$ & $(0.056)$ & $(0.034)$ & (0.068) & $(0.088)$ & $(0.046)$ & $(0.056)$ \\
\hline \multirow[t]{2}{*}{ Neuroticism (std) } & $-0.110 * *$ & -0.064 & -0.032 & -0.062 & -0.103 & $-0.093 * *$ & -0.055 \\
\hline & $(0.055)$ & $(0.052)$ & $(0.036)$ & (0.074) & $(0.087)$ & $(0.047)$ & $(0.057)$ \\
\hline \multirow{2}{*}{ Agreeableness (std) } & -0.025 & -0.021 & 0.029 & -0.059 & -0.186 & -0.003 & -0.088 \\
\hline & $(0.062)$ & $(0.064)$ & $(0.040)$ & (0.069) & $(0.116)$ & $(0.052)$ & $(0.066)$ \\
\hline \multirow[t]{2}{*}{ Conscientiousness (std) } & -0.080 & -0.002 & -0.003 & 0.060 & 0.091 & -0.062 & 0.029 \\
\hline & $(0.060)$ & $(0.046)$ & $(0.032)$ & $(0.066)$ & $(0.086)$ & (0.051) & $(0.046)$ \\
\hline \multirow[t]{2}{*}{ Openness (std) } & 0.049 & 0.006 & 0.006 & $0.156^{*}$ & -0.076 & 0.003 & 0.058 \\
\hline & $(0.057)$ & $(0.055)$ & $(0.035)$ & $(0.080)$ & $(0.118)$ & $(0.055)$ & $(0.067)$ \\
\hline \multirow[t]{2}{*}{ PPVT Score (W1) } & 0.017 & 0.050 & $0.142 * *$ & -0.011 & 0.090 & $0.131^{*}$ & 0.070 \\
\hline & (0.097) & $(0.092)$ & $(0.055)$ & (0.074) & $(0.147)$ & $(0.072)$ & $(0.091)$ \\
\hline Observations & 685 & 699 & 1,272 & 453 & 303 & 827 & 865 \\
\hline R-squared & 0.066 & 0.034 & 0.098 & 0.078 & 0.066 & 0.104 & 0.061 \\
\hline Number of Families & 344 & 380 & 673 & 230 & 164 & 434 & 460 \\
\hline
\end{tabular}

$1 \%{ }^{* * *}, 5 \% * *, 10 \% *$, Robust Standard Errors clustered at the school or family level. Same controls as previous table. Rich: above median household income at wave 1. Poor: below median household income at wave 1. 
Appendix Tables

Table 1A

Descriptive Statistics: Add Health

Comparison of Full Sample and Sibling Sample

\begin{tabular}{|c|c|c|c|c|c|c|c|}
\hline Variable & Wave & Obs & Mean & Std Dev & Obs & Mean & Std Dev \\
\hline Any Income & 4 & 14527 & 0.93 & 0.25 & 2346 & 0.93 & 0.26 \\
\hline Work (10+ Hours) & 4 & 12304 & 0.77 & 0.42 & 1957 & 0.76 & 0.43 \\
\hline Earnings & 4 & 14527 & 34232.25 & 37594.21 & 2346 & 34271.22 & 38724.15 \\
\hline Log(Earnings) & 4 & 13523 & 10.15 & 1.04 & 2175 & 10.17 & 1.00 \\
\hline Log(Earnings) with Zeros & 4 & 14527 & 9.29 & 3.31 & 2346 & 9.26 & 3.38 \\
\hline Earnings Guess & 4 & 14527 & 0.03 & 0.16 & 2346 & 0.02 & 0.15 \\
\hline Extraversion Scale & 4 & 14527 & 13.23 & 3.06 & 2346 & 13.16 & 3.05 \\
\hline Neuroticism Scale & 4 & 14527 & 10.43 & 2.74 & 2346 & 10.41 & 2.75 \\
\hline Agreeableness Scale & 4 & 14527 & 15.26 & 2.41 & 2346 & 15.19 & 2.44 \\
\hline Conscientiousness Scale & 4 & 14527 & 14.65 & 2.69 & 2346 & 14.81 & 2.65 \\
\hline Openness Scale & 4 & 14527 & 14.50 & 2.45 & 2346 & 14.35 & 2.48 \\
\hline Extraversion Scale (std) & 4 & 14527 & 0.00 & 1.00 & 2346 & -0.02 & 1.00 \\
\hline Neuroticism Scale (std) & 4 & 14527 & -0.01 & 1.00 & 2346 & -0.02 & 1.00 \\
\hline Agreeableness Scale (std) & 4 & 14527 & 0.01 & 1.00 & 2346 & -0.02 & 1.01 \\
\hline Conscientiousness Scale (std) & 4 & 14527 & 0.00 & 1.00 & 2346 & 0.06 & 0.98 \\
\hline Openness Scale (std) & 4 & 14527 & 0.00 & 1.00 & 2346 & -0.06 & 1.01 \\
\hline Age & 4 & 14527 & 28.97 & 1.75 & 2346 & 28.96 & 1.69 \\
\hline Female & All & 14527 & 0.54 & 0.50 & 2346 & 0.52 & 0.50 \\
\hline PPVT Score & 1 & 14527 & 100.80 & 14.44 & 2346 & 99.89 & 14.05 \\
\hline Maternal Education & 1 & 14527 & 13.22 & 2.24 & 2346 & 13.16 & 2.26 \\
\hline Family Income & 1 & 14527 & 46.12 & 42.17 & 2346 & 46.59 & 45.49 \\
\hline Married Parents & 1 & 14527 & 0.71 & 0.42 & 2346 & 0.73 & 0.41 \\
\hline Hispanic & All & 14527 & 0.16 & 0.37 & 2346 & 0.14 & 0.34 \\
\hline Black & All & 14527 & 0.22 & 0.41 & 2346 & 0.21 & 0.41 \\
\hline Rural & 1 & 14527 & 0.26 & 0.43 & 2346 & 0.31 & 0.46 \\
\hline Missing Family Information & 1 & 14527 & 0.31 & 0.46 & 2346 & 0.29 & 0.45 \\
\hline Grade $=8$ & 1 & 14205 & 0.14 & 0.35 & 2338 & 0.13 & 0.33 \\
\hline Grade $=9$ & 1 & 14205 & 0.18 & 0.39 & 2338 & 0.20 & 0.40 \\
\hline Grade $=10$ & 1 & 14205 & 0.19 & 0.40 & 2338 & 0.19 & 0.39 \\
\hline Grade $=11$ & 1 & 14205 & 0.19 & 0.39 & 2338 & 0.20 & 0.40 \\
\hline Grade $=12$ & 1 & 14205 & 0.16 & 0.36 & 2338 & 0.15 & 0.35 \\
\hline PPVT Score & 3 & 14527 & 101.08 & 14.14 & 2346 & 100.41 & 14.49 \\
\hline Missing PPVT & 3 & 14527 & 0.19 & 0.39 & 2346 & 0.15 & 0.36 \\
\hline Below Average Attractiveness & 4 & 14504 & 0.07 & 0.26 & 2343 & 0.07 & 0.25 \\
\hline Above Average Attractiveness & 4 & 14504 & 0.46 & 0.50 & 2343 & 0.46 & 0.50 \\
\hline Education & 4 & 14525 & 14.29 & 2.06 & 2346 & 14.26 & 2.08 \\
\hline Ever Married & 4 & 14520 & 0.50 & 0.50 & 2345 & 0.52 & 0.50 \\
\hline
\end{tabular}


Table 2A

Descriptive Statistics: Add Health

Full Sample Stratified by Gender

\begin{tabular}{|c|c|c|c|c|c|c|c|}
\hline & & Males & & & Females & & \\
\hline Variable & Wave & Obs & Mean & Std Dev & Obs & Mean & Std Dev \\
\hline Any Income & 4 & 6755 & 0.97 & 0.18 & 7772 & 0.90 & 0.30 \\
\hline \multirow[t]{2}{*}{ Work (10+ Hours) } & 4 & 5734 & 0.81 & 0.39 & 6570 & 0.73 & 0.44 \\
\hline & & & 40562.1 & 40812.7 & & 28730.6 & 33601.7 \\
\hline Earnings & 4 & 6755 & 4 & 4 & 7772 & 5 & 3 \\
\hline Log(Earnings) & 4 & 6524 & 10.31 & 1.00 & 6999 & 9.99 & 1.05 \\
\hline Log(Earnings) with Zeros & 4 & 6755 & 9.88 & 2.49 & 7772 & 8.77 & 3.81 \\
\hline Earnings Guess & 4 & 6755 & 0.02 & 0.15 & 7772 & 0.03 & 0.17 \\
\hline Extraversion Scale & 4 & 6755 & 13.10 & 3.06 & 7772 & 13.34 & 3.06 \\
\hline Neuroticism Scale & 4 & 6755 & 9.84 & 2.61 & 7772 & 10.94 & 2.75 \\
\hline Agreeableness Scale & 4 & 6755 & 14.59 & 2.47 & 7772 & 15.85 & 2.19 \\
\hline Conscientiousness Scale & 4 & 6755 & 14.41 & 2.62 & 7772 & 14.86 & 2.74 \\
\hline Openness Scale & 4 & 6755 & 14.81 & 2.48 & 7772 & 14.24 & 2.39 \\
\hline Extraversion Scale (std) & 4 & 6755 & -0.04 & 1.00 & 7772 & 0.04 & 1.00 \\
\hline Neuroticism Scale (std) & 4 & 6755 & -0.22 & 0.95 & 7772 & 0.18 & 1.00 \\
\hline Agreeableness Scale (std) & 4 & 6755 & -0.27 & 1.02 & 7772 & 0.26 & 0.91 \\
\hline Conscientiousness Scale (std) & 4 & 6755 & -0.09 & 0.97 & 7772 & 0.08 & 1.02 \\
\hline Openness Scale (std) & 4 & 6755 & 0.13 & 1.01 & 7772 & -0.10 & 0.97 \\
\hline Age & 4 & 6755 & 29.08 & 1.75 & 7772 & 28.87 & 1.74 \\
\hline Female & All & 6755 & 0.00 & 0.00 & 7772 & 1.00 & 0.00 \\
\hline PPVT Score & 1 & 6755 & 101.72 & 14.41 & 7772 & 100.01 & 14.42 \\
\hline Maternal Education & 1 & 6755 & 13.29 & 2.25 & 7772 & 13.16 & 2.24 \\
\hline Family Income & 1 & 6755 & 45.88 & 37.91 & 7772 & 46.32 & 45.55 \\
\hline Married Parents & 1 & 6755 & 0.72 & 0.42 & 7772 & 0.70 & 0.43 \\
\hline Hispanic & All & 6755 & 0.16 & 0.37 & 7772 & 0.16 & 0.36 \\
\hline Black & All & 6755 & 0.20 & 0.40 & 7772 & 0.23 & 0.42 \\
\hline Rural & 1 & 6755 & 0.26 & 0.44 & 7772 & 0.26 & 0.43 \\
\hline Missing Family Information & 1 & 6755 & 0.30 & 0.46 & 7772 & 0.31 & 0.46 \\
\hline Grade $=8$ & 1 & 6617 & 0.14 & 0.35 & 7588 & 0.14 & 0.35 \\
\hline Grade $=9$ & 1 & 6617 & 0.18 & 0.39 & 7588 & 0.18 & 0.39 \\
\hline Grade $=10$ & 1 & 6617 & 0.20 & 0.40 & 7588 & 0.19 & 0.39 \\
\hline Grade $=11$ & 1 & 6617 & 0.19 & 0.39 & 7588 & 0.19 & 0.39 \\
\hline Grade $=12$ & 1 & 6617 & 0.15 & 0.36 & 7588 & 0.16 & 0.37 \\
\hline PPVT Score & 3 & 6755 & 101.63 & 13.73 & 7772 & 100.60 & 14.46 \\
\hline Missing PPVT & 3 & 6755 & 0.22 & 0.41 & 7772 & 0.17 & 0.38 \\
\hline Below Average Attractiveness & 4 & 6742 & 0.07 & 0.25 & 7762 & 0.07 & 0.26 \\
\hline Above Average Attractiveness & 4 & 6742 & 0.42 & 0.49 & 7762 & 0.49 & 0.50 \\
\hline Education & 4 & 6753 & 14.03 & 2.03 & 7772 & 14.51 & 2.06 \\
\hline Ever Married & 4 & 6749 & 0.46 & 0.50 & 7771 & 0.53 & 0.50 \\
\hline
\end{tabular}


Table 3A

Associations Between Any Earnings and Cognitive and Non-Cognitive Skills Baseline, School, Occupation, and Family Fixed Effects

\begin{tabular}{|c|c|c|c|c|c|}
\hline Outcome & $\begin{array}{c}\text { Any } \\
\text { Earnings }\end{array}$ & $\begin{array}{c}\text { Any } \\
\text { Earnings }\end{array}$ & $\begin{array}{c}\text { Any } \\
\text { Earnings }\end{array}$ & $\begin{array}{c}\text { Any } \\
\text { Earnings }\end{array}$ & $\begin{array}{c}\text { Any } \\
\text { Earnings }\end{array}$ \\
\hline Fixed Effects? & None & School & Occupation & Family & Family \\
\hline Xs & Basic & Basic & Extra & Basic & Extra \\
\hline Extraversion (std) & $\begin{array}{c}0.016^{* * *} \\
(0.003)\end{array}$ & $\begin{array}{c}0.015^{* * *} \\
(0.003)\end{array}$ & $\begin{array}{c}0.011^{* * *} \\
(0.003)\end{array}$ & $\begin{array}{c}0.007 \\
(0.009)\end{array}$ & $\begin{array}{c}0.006 \\
(0.009)\end{array}$ \\
\hline Neuroticism (std) & $\begin{array}{c}-0.006 * * \\
(0.003)\end{array}$ & $\begin{array}{c}-0.008 * * * \\
(0.003)\end{array}$ & $\begin{array}{l}-0.004^{*} \\
(0.002)\end{array}$ & $\begin{array}{l}-0.007 \\
(0.008)\end{array}$ & $\begin{array}{l}-0.006 \\
(0.009)\end{array}$ \\
\hline Agreeableness (std) & $\begin{array}{l}-0.005 \\
(0.003)\end{array}$ & $\begin{array}{l}-0.005^{*} \\
(0.003)\end{array}$ & $\begin{array}{c}-0.009 * * * \\
(0.003)\end{array}$ & $\begin{array}{l}-0.007 \\
(0.010)\end{array}$ & $\begin{array}{l}-0.007 \\
(0.010)\end{array}$ \\
\hline Conscientiousness (std) & $\begin{array}{c}0.004 \\
(0.003)\end{array}$ & $\begin{array}{c}0.003 \\
(0.003)\end{array}$ & $\begin{array}{l}-0.001 \\
(0.002)\end{array}$ & $\begin{array}{c}0.019 * * \\
(0.008)\end{array}$ & $\begin{array}{c}0.018 * * \\
(0.008)\end{array}$ \\
\hline Openness (std) & $\begin{array}{l}-0.000 \\
(0.003)\end{array}$ & $\begin{array}{c}0.002 \\
(0.003)\end{array}$ & $\begin{array}{c}0.001 \\
(0.002)\end{array}$ & $\begin{array}{l}-0.004 \\
(0.009)\end{array}$ & $\begin{array}{l}-0.006 \\
(0.009)\end{array}$ \\
\hline Age & $\begin{array}{c}-0.012^{* *} \\
(0.005)\end{array}$ & $\begin{array}{c}-0.011^{* *} \\
(0.004)\end{array}$ & $\begin{array}{l}-0.003 \\
(0.004)\end{array}$ & $\begin{array}{l}-0.002 \\
(0.005)\end{array}$ & $\begin{array}{l}-0.001 \\
(0.005)\end{array}$ \\
\hline Female & $\begin{array}{c}-0.061 * * * \\
(0.007)\end{array}$ & $\begin{array}{c}-0.061 * * * \\
(0.007)\end{array}$ & $\begin{array}{c}-0.053 * * * \\
(0.010)\end{array}$ & $\begin{array}{c}-0.085 * * * \\
(0.017)\end{array}$ & $\begin{array}{c}-0.089 * * * \\
(0.017)\end{array}$ \\
\hline PPVT Score (W1) & $\begin{array}{c}0.017^{* * *} \\
(0.004)\end{array}$ & $\begin{array}{c}0.014^{* * *} \\
(0.004)\end{array}$ & $\begin{array}{c}0.003 \\
(0.003)\end{array}$ & $\begin{array}{l}-0.001 \\
(0.011)\end{array}$ & $\begin{array}{l}-0.005 \\
(0.011)\end{array}$ \\
\hline Hispanic & $\begin{array}{c}0.007 \\
(0.009)\end{array}$ & $\begin{array}{c}0.005 \\
(0.010)\end{array}$ & $\begin{array}{l}0.013^{*} \\
(0.007)\end{array}$ & & \\
\hline Black & $\begin{array}{l}0.016 * \\
(0.008)\end{array}$ & $\begin{array}{c}0.016 \\
(0.011)\end{array}$ & $\begin{array}{l}0.018 * \\
(0.010)\end{array}$ & & \\
\hline PPVT Score (W3) & & & $\begin{array}{c}0.001 \\
(0.002)\end{array}$ & & $\begin{array}{c}0.003 \\
(0.009)\end{array}$ \\
\hline Education & & & $\begin{array}{c}0.008^{* * *} \\
(0.003)\end{array}$ & & $\begin{array}{l}0.009 * \\
(0.005)\end{array}$ \\
\hline Ever Married & & & $\begin{array}{c}-0.031^{* * *} \\
(0.009)\end{array}$ & & $\begin{array}{l}-0.023^{*} \\
(0.014)\end{array}$ \\
\hline Below Average Attractiveness & & & $\begin{array}{c}-0.021 * * \\
(0.008)\end{array}$ & & $\begin{array}{l}-0.032 \\
(0.031)\end{array}$ \\
\hline Above Average Attractiveness & & & $\begin{array}{c}0.010 * * * \\
(0.003)\end{array}$ & & $\begin{array}{l}-0.005 \\
(0.016)\end{array}$ \\
\hline Observations & 13,433 & 13,433 & 13,898 & 2,346 & 2,342 \\
\hline R-squared & 0.034 & 0.058 & 0.031 & 0.035 & 0.041 \\
\hline Number of Families & & & & 1,120 & 1,120 \\
\hline
\end{tabular}

$1 \% * * *, 5 \% * *, 10 \% *$, Robust Standard Errors clustered at the school or family level. Omitted Controls: Grade Level at Wave 1 Dummies, Missing PPVT W3 Score, Missing Family Information, Rural Status, Constant, Family Income, Maternal Education 
Table 4A

Associations Between Log Earnings (Including Zeros) and Cognitive and Non-Cognitive Skills Baseline, School, Occupation, and Family Fixed Effects

\begin{tabular}{|c|c|c|c|c|c|}
\hline Outcome & $\begin{array}{c}\text { Log } \\
\text { (Earnings) }\end{array}$ & Log (Earnings) & $\begin{array}{c}\text { Log } \\
\text { (Earnings) }\end{array}$ & $\begin{array}{c}\text { Log } \\
\text { (Earnings) }\end{array}$ & $\begin{array}{c}\text { Log } \\
\text { (Earnings) }\end{array}$ \\
\hline Fixed Effects? & None & School & Occupation & Family & Family \\
\hline Xs & Basic & Basic & Extra & Basic & Extra \\
\hline \multirow[t]{2}{*}{ Extraversion (std) } & $0.250 * * *$ & $0.232 * * *$ & $0.198 * * *$ & 0.125 & 0.106 \\
\hline & $(0.043)$ & $(0.044)$ & $(0.043)$ & $(0.117)$ & $(0.117)$ \\
\hline \multirow[t]{2}{*}{ Neuroticism (std) } & $-0.157 * * *$ & $-0.174 * * *$ & $-0.092 * * *$ & -0.122 & -0.096 \\
\hline & $(0.041)$ & $(0.040)$ & $(0.026)$ & $(0.107)$ & $(0.108)$ \\
\hline \multirow[t]{2}{*}{ Agreeableness (std) } & -0.057 & $-0.063 *$ & $-0.137 * * *$ & -0.092 & -0.108 \\
\hline & (0.039) & $(0.038)$ & $(0.037)$ & $(0.123)$ & $(0.125)$ \\
\hline \multirow{2}{*}{ Conscientiousness (std) } & $0.102 * *$ & $0.094 * *$ & 0.020 & $0.226 * *$ & $0.202 * *$ \\
\hline & $(0.044)$ & $(0.042)$ & $(0.032)$ & $(0.098)$ & $(0.097)$ \\
\hline \multirow[t]{2}{*}{ Openness (std) } & -0.010 & -0.012 & -0.029 & -0.029 & -0.061 \\
\hline & $(0.042)$ & $(0.040)$ & $(0.030)$ & $(0.115)$ & $(0.112)$ \\
\hline \multirow[t]{2}{*}{ Age } & $-0.236 * * *$ & $-0.226 * * *$ & -0.079 & 0.024 & 0.012 \\
\hline & $(0.059)$ & $(0.056)$ & $(0.052)$ & $(0.060)$ & $(0.061)$ \\
\hline \multirow[t]{2}{*}{ Female } & $-1.060 * * *$ & $-1.079 * * *$ & $-0.921 * * *$ & $-1.362 * * *$ & $-1.458 * * *$ \\
\hline & $(0.097)$ & $(0.097)$ & $(0.153)$ & $(0.217)$ & $(0.219)$ \\
\hline \multirow[t]{2}{*}{ PPVT Score (W1) } & $0.312 * * *$ & $0.261^{* * *}$ & 0.067 & 0.032 & -0.059 \\
\hline & $(0.052)$ & $(0.047)$ & $(0.045)$ & (0.139) & $(0.142)$ \\
\hline \multirow[t]{2}{*}{ Parents Married } & $0.334 * * *$ & $0.287^{* * *}$ & $0.195^{* *}$ & & \\
\hline & $(0.107)$ & $(0.106)$ & $(0.070)$ & & \\
\hline \multirow[t]{2}{*}{ Hispanic } & 0.123 & 0.038 & $0.170^{*}$ & & \\
\hline & $(0.131)$ & $(0.143)$ & $(0.093)$ & & \\
\hline \multirow[t]{2}{*}{ Black } & 0.036 & 0.017 & 0.090 & & \\
\hline & $(0.122)$ & $(0.141)$ & $(0.135)$ & & \\
\hline \multirow[t]{2}{*}{ PPVT Score (W3) } & & & 0.020 & & 0.062 \\
\hline & & & $(0.027)$ & & $(0.116)$ \\
\hline \multirow[t]{2}{*}{ Education } & & & $0.194 * * *$ & & $0.189 * * *$ \\
\hline & & & $(0.038)$ & & $(0.060)$ \\
\hline \multirow[t]{2}{*}{ Ever Married } & & & $-0.295 * *$ & & -0.153 \\
\hline & & & $(0.123)$ & & $(0.177)$ \\
\hline \multirow[t]{2}{*}{ Below Average Attractiveness } & & & $-0.327^{* * *}$ & & -0.442 \\
\hline & & & $(0.102)$ & & $(0.398)$ \\
\hline \multirow[t]{2}{*}{ Above Average Attractiveness } & & & $0.197 * * *$ & & -0.007 \\
\hline & & & $(0.052)$ & & $(0.196)$ \\
\hline Observations & 13,433 & 13,433 & 13,898 & 2,346 & 2,342 \\
\hline R-squared & 0.064 & 0.090 & 0.051 & 0.051 & 0.060 \\
\hline Number of Families & & & & 1,120 & 1,120 \\
\hline
\end{tabular}

$1 \%{ }^{* * *}, 5 \%{ }^{* *}, 10 \% *$, Robust Standard Errors clustered at the school or family level. Omitted Controls: Grade Level at Wave 1 Dummies, Missing PPVT W3 Score, Missing Family Information, Rural Status, Constant, Family Income, Maternal Education 
Table 5A

Associations Between Log Earnings (No Guesses) and Cognitive and Non-Cognitive Skills Baseline, School, Occupation, and Family Fixed Effects

\begin{tabular}{|c|c|c|c|c|c|}
\hline Outcome & $\begin{array}{c}\text { Log } \\
\text { Earnings }\end{array}$ & $\begin{array}{c}\text { Log } \\
\text { Earnings }\end{array}$ & $\begin{array}{c}\text { Log } \\
\text { Earnings }\end{array}$ & $\begin{array}{c}\text { Log } \\
\text { Earnings }\end{array}$ & $\begin{array}{c}\text { Log } \\
\text { Earnings }\end{array}$ \\
\hline Fixed Effects? & None & School & Occupation & Family & Family \\
\hline Xs & Basic & Basic & Extra & Basic & Extra \\
\hline Extraversion (std) & $\begin{array}{c}0.061^{* * *} \\
(0.012)\end{array}$ & $\begin{array}{c}0.055^{* * *} \\
(0.012)\end{array}$ & $\begin{array}{c}0.066^{* * *} \\
(0.009)\end{array}$ & $\begin{array}{c}0.044 \\
(0.031)\end{array}$ & $\begin{array}{c}0.039 \\
(0.031)\end{array}$ \\
\hline Neuroticism (std) & $\begin{array}{c}-0.086 * * * \\
(0.016)\end{array}$ & $\begin{array}{c}-0.084^{* * *} \\
(0.015)\end{array}$ & $\begin{array}{c}-0.047^{* * *} \\
(0.007)\end{array}$ & $\begin{array}{c}-0.062^{* *} \\
(0.031)\end{array}$ & $\begin{array}{c}-0.053 * \\
(0.031)\end{array}$ \\
\hline Agreeableness (std) & $\begin{array}{l}-0.000 \\
(0.014)\end{array}$ & $\begin{array}{c}-0.008 \\
(0.014)\end{array}$ & $\begin{array}{c}-0.033^{* * *} \\
(0.011)\end{array}$ & $\begin{array}{l}-0.017 \\
(0.035)\end{array}$ & $\begin{array}{l}-0.037 \\
(0.035)\end{array}$ \\
\hline Conscientiousness (std) & $\begin{array}{c}0.059 * * * \\
(0.012)\end{array}$ & $\begin{array}{c}0.059 * * * \\
(0.011)\end{array}$ & $\begin{array}{c}0.030 * * * \\
(0.010)\end{array}$ & $\begin{array}{l}-0.003 \\
(0.030)\end{array}$ & $\begin{array}{l}-0.012 \\
(0.029)\end{array}$ \\
\hline Openness (std) & $\begin{array}{l}-0.015 \\
(0.019)\end{array}$ & $\begin{array}{c}-0.035^{* *} \\
(0.014)\end{array}$ & $\begin{array}{c}-0.043^{* * *} \\
(0.009)\end{array}$ & $\begin{array}{c}0.039 \\
(0.034)\end{array}$ & $\begin{array}{c}0.032 \\
(0.033)\end{array}$ \\
\hline Age & $\begin{array}{c}-0.095 * * * \\
(0.024)\end{array}$ & $\begin{array}{c}-0.090 * * * \\
(0.022)\end{array}$ & $\begin{array}{c}-0.050^{* * *} \\
(0.017)\end{array}$ & $\begin{array}{c}0.069 * * * \\
(0.019)\end{array}$ & $\begin{array}{c}0.055^{* * *} \\
(0.019)\end{array}$ \\
\hline Female & $\begin{array}{c}-0.332 * * * \\
(0.037)\end{array}$ & $\begin{array}{c}-0.356 * * * \\
(0.032)\end{array}$ & $\begin{array}{c}-0.289 * * * \\
(0.049)\end{array}$ & $\begin{array}{c}-0.328 * * * \\
(0.068)\end{array}$ & $\begin{array}{c}-0.373 * * * \\
(0.067)\end{array}$ \\
\hline PPVT Score (W1) & $\begin{array}{c}0.119 * * * \\
(0.024)\end{array}$ & $\begin{array}{c}0.096 * * * \\
(0.017)\end{array}$ & $\begin{array}{l}0.028^{*} \\
(0.016)\end{array}$ & $\begin{array}{c}0.048 \\
(0.047)\end{array}$ & $\begin{array}{c}0.015 \\
(0.047)\end{array}$ \\
\hline Parents Married & $\begin{array}{c}0.103^{* *} \\
(0.048)\end{array}$ & $\begin{array}{c}0.065 \\
(0.042)\end{array}$ & $\begin{array}{c}0.054^{* *} \\
(0.026)\end{array}$ & & \\
\hline Hispanic & $\begin{array}{c}0.036 \\
(0.056)\end{array}$ & $\begin{array}{c}-0.017 \\
(0.055)\end{array}$ & $\begin{array}{c}0.006 \\
(0.028)\end{array}$ & & \\
\hline Black & $\begin{array}{c}-0.163^{* * *} \\
(0.060)\end{array}$ & $\begin{array}{c}-0.199 * * * \\
(0.053)\end{array}$ & $\begin{array}{c}-0.137^{* * *} \\
(0.031)\end{array}$ & & \\
\hline PPVT Score (W3) & & & $\begin{array}{c}0.006 \\
(0.013)\end{array}$ & & $\begin{array}{c}-0.001 \\
(0.037)\end{array}$ \\
\hline Education & & & $\begin{array}{c}0.101 * * * \\
(0.014)\end{array}$ & & $\begin{array}{c}0.085^{* * *} \\
(0.018)\end{array}$ \\
\hline Ever Married & & & $\begin{array}{c}0.087 * * * \\
(0.028)\end{array}$ & & $\begin{array}{c}0.122 * * \\
(0.055)\end{array}$ \\
\hline Below Average Attractiveness & & & $\begin{array}{c}-0.084 * * \\
(0.034)\end{array}$ & & $\begin{array}{c}0.034 \\
(0.111)\end{array}$ \\
\hline Above Average Attractiveness & & & $\begin{array}{c}0.078 * * * \\
(0.021)\end{array}$ & & $\begin{array}{c}0.066 \\
(0.056)\end{array}$ \\
\hline Observations & 12,167 & 12,167 & 12,631 & 2,118 & 2,114 \\
\hline R-squared & 0.113 & 0.188 & 0.098 & 0.063 & 0.086 \\
\hline Number of Families & & & & 1,101 & 1,101 \\
\hline
\end{tabular}

$1 \%{ }^{* * *}, 5 \% * *, 10 \% *$, Robust Standard Errors clustered at the school or family level. Omitted Controls: Grade Level at Wave 1 Dummies, Missing PPVT W3 Score, Missing Family Information, Rural Status, Constant, Family Income, Maternal Education 